\title{
Properties of Ceria Based Novel Anode Nanopowders Synthesized by Glycine-Nitrate Process
}

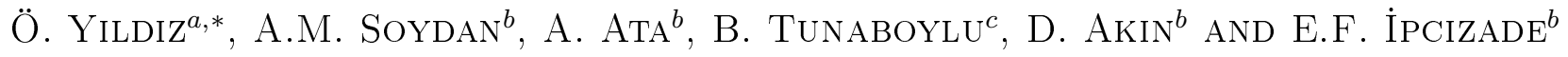 \\ ${ }^{a}$ Kocaeli University, Faculty of Engineering, Department of Metallurgical and Materials Engineering \\ TR-41380 Kocaeli, Turkey \\ ${ }^{b}$ Gebze Institute of Technology, Faculty of Engineering, Department of Materials Science and Engineering \\ TR-41400 Gebze/Kocaeli, Turkey \\ ${ }^{c}$ Istanbul Sehir University, TR-34100 İstanbul, Turkey
}

\begin{abstract}
Novel anode nanopowder materials consisting of ceria-based components synthesized by glycine-nitrate process were investigated for solid oxide fuel cells. Glycine-nitrate process involves a self-combustion reaction at $220{ }^{\circ} \mathrm{C}$ of water-based nitrate and glycine solutions which subsequently can reach up to $1200{ }^{\circ} \mathrm{C}$. The resulting morphology, the size of particles and the formation of crystalline phases were characterized by differential scanning calorimetry, X-ray diffraction, transmission electron microscopy, scanning electron microscopy, the Brunauer-Emmett-Teller method and Nanosizer. It was determined that dopants in ceria such as Co, Ni, Cu, V and Fe had significant effect on the morphology and size. The size distribution measured by Nanosizer was 50-600 nm, transmission electron microscopy, 5-200 nm and the Brunauer-Emmett-Teller method 100-120 nm and specific surface area of powders in the range $67.45-72.05 \mathrm{~m}^{2} \mathrm{~g}^{-1}$ as measured by the Brunauer-Emmett-Teller method. Particles were observed to have spherical structures for $\mathrm{Cu}$ and Fe doped powders and rod-shaped in a porous tuff microstructure for those doped with Co and Ni. Vanadium doping helped to decrease the porosity and initiated the process of spheroidization of particles.
\end{abstract}

DOI: 10.12693/APhysPolA.123.432

PACS: 82.47.Ed, 81.07.Wx, 81.20.Ka, 81.20.Ev, 81.05.Mh, 61.46.Df

\section{Introduction}

Solid oxide fuel cells (SOFCs) will offer the highest electricity generation efficiency from fossil fuels. However, the system has not become a commercial commodity yet. The main reason is the cost due to the high temperature resistant materials used and some high temperature problems such as unwanted reactions and sealing of cells $[1-3]$. There are many studies to lower the operation temperatures from $1000^{\circ} \mathrm{C}$ to $800{ }^{\circ} \mathrm{C}$ range which would enable employing low cost cell materials. The cell system consists of three layers: anode, cathode and electrolyte. The anode side determines the catalytic oxidation of fuel or dissociation reaction of methane and hence the overall reaction. For fabrication of intermediate-temperature $\left(800^{\circ} \mathrm{C}\right)$ SOFC anode, which has high catalytic activity and porous structure, the low cost raw powder materials are needed.

The ceria is mentioned in several studies as an excellent catalyzer for oxidation of methane gas and some other gaseous and liquid hydrocarbons. It avoids carbon deposition and shows resistance to sulfur poisoning [3-7]. Both reinforced and unreinforced ceria show good ionic and electronic conductivity in low partial pressures of oxygen. However, the lattice structure of ceria expands at low partial pressures, and this expansion causes cracks in the material [4]. Ceria should be supported

*corresponding author; e-mail: oyildiz@kocaeli.edu.tr with cations of transition metals, such as $\mathrm{Ni}, \mathrm{Cu}$ and $\mathrm{Co}$ to prevent the damage. A popular method to incorporate these cations is glycine-nitrate process (GNP). GNP is a self-combustion method for ceramic composite powder manufacturing used in many fields from flat panel displays to lithium batteries. It uses amino acetic acid (glycine) as a fuel and metal nitrate of the targeted composition as an oxidant for combustion process. Glycine serves in a dual role in the GNP process. In the precursor solution, it prevents selective precipitation in the glycine complexes of metal cations and it oxidizes the nitrate anions, serving as a fuel [5].

Physical properties of the synthesized powders are directly influenced by the amount of constituents. The average particle size decreases and the specific surface area increases with increasing glycine amount in the starting composition. GNP is a simple and cost-effective method with less labor which enable very high production rates $[8,9]$. These advantages of GNP process are due to some characteristics which can be summarized as fine crystalline powders with easily broken agglomerates, nanometer scale particle size, high chemical homogeneity, milling with no need for crashing, no impurities from milling process, narrow range powder size distribution.

In this work, ceria powders containing $\mathrm{Co}$ and $\mathrm{Ni}$ metallic particles were modified further by addition of cations $\mathrm{Cu}, \mathrm{V}$ and $\mathrm{Fe}$. The morphology and properties of the resulting powder mixture were investigated by $\mathrm{X}$-ray diffraction (XRD), differential scanning calorimetry (DSC), electron microscopy (scanning, SEM, and 
transmission, TEM) and the Brunauer-Emmett-Teller (BET) analyses. The synthesized powders are targeted to be used as anode material with a high ionic activity for microtubular SOFC.

\section{Experimental}

$\mathrm{Ce}\left(\mathrm{NO}_{3}\right)_{3} \cdot 6 \mathrm{H}_{2} \mathrm{O}, \mathrm{Ni}\left(\mathrm{NO}_{3}\right)_{2} \cdot 6 \mathrm{H}_{2} \mathrm{O}, \mathrm{Co}\left(\mathrm{NO}_{3}\right)_{2} \cdot 6 \mathrm{H}_{2} \mathrm{O}$, $\mathrm{Cu}\left(\mathrm{NO}_{3}\right)_{2} 2.5 \mathrm{H}_{2} \mathrm{O}$ and glycine $\left(\mathrm{NH}_{2} \mathrm{CH}_{2} \mathrm{COOH}\right)$ with a purity of $\approx 99.5$ wt\% from Alfa Aesar, Merck and Aldrich were used as starting raw materials to prepare ceria based nanopowders.

\subsection{Synthesis}

In this study, ceria based powder compositions (Table) with 19 different combinations of metal nitrate (cobalt, nickel, copper, vanadium and iron nitrates) with varying amounts were synthesized using GNP. At first stage, metal nitrate solutions with certain stoichiometric ratios were prepared with pure water. Molar ratio of glycine and nitrate in the final composition was adjusted to $1: 1$. The solution was mixed and heated to $\approx 100{ }^{\circ} \mathrm{C}$ in a glass beaker for $\mathrm{H}_{2} \mathrm{O}$ evaporation. After the evaporation, the beaker was placed into a specially designed stainless-steel 316 explosion reactor and heated to $\approx 220^{\circ} \mathrm{C}$. After the combustion reaction, a powder product was obtained which appeared in volcano tuff form with soft agglomerates $[10,11]$ :

Ce\&Metal Nitrate + Glycine solution
$\longrightarrow$ Stirring \& Evaporation
$\longrightarrow$ Combustion $\left(\sim 220^{\circ} \mathrm{C}\right) \rightarrow$ Product

The synthesized powders were ground with an agate mortar, and then ball milled in an ethyl alcohol solution for $6 \mathrm{~h}$ to characterize morphology and other properties.

\subsection{Characterization}

The prepared powders were characterized by dynamic DSC, XRD, SEM, energy dispersive X-ray spectroscopy (EDS), TEM and BET techniques. The thermal behavior of powders were determined by DSC (STA 449C from Netzsch) with a heating rate of $5 \mathrm{~K} \mathrm{~min}^{-1}$ in atmospheric conditions. The crystallization and crystal structures were observed using XRD (Rigaku Dmax 2200 Diffractometer, $\mathrm{Cu} K_{\alpha}$ radiation and wavelength of $\lambda=1.54060 \AA$ ). The microstructural characterization of particle size, shape and morphology of the powder materials were done by using Philips XL30 SFEG Type Electron Microscope. The crystallinity, the morphology, the grain size and the elemental EDS analysis of the nanopowders were examined by TEM (Philips Tecnai). The particle size and specific surface area of the synthesized powders were measured using by Nano sizer from Malvern and BET method (Quantachrome Autosorb 1B), respectively.

\section{TABLE}

The composition of the synthesized powders.

\begin{tabular}{c|l}
\hline \hline No. & \multicolumn{1}{c}{ Composition } \\
\hline 1 & $\mathrm{Ce}\left(\mathrm{Co}_{0.30}, \mathrm{Ni}_{0.45}, \mathrm{Cu}_{0.15}, \mathrm{~V}_{0.05}, \mathrm{Fe}_{0.05}\right) \mathrm{O}_{3}$ \\
2 & $\mathrm{Ce}\left(\mathrm{Co}_{0.35}, \mathrm{Ni}_{0.45}, \mathrm{Cu}_{0.10}, \mathrm{~V}_{0.05}, \mathrm{Fe}_{0.05}\right) \mathrm{O}_{3}$ \\
3 & $\mathrm{Ce}\left(\mathrm{Co}_{0.40}, \mathrm{Ni}_{0.45}, \mathrm{Cu}_{0.05}, \mathrm{~V}_{0.05}, \mathrm{Fe}_{0.05}\right) \mathrm{O}_{3}$ \\
4 & $\mathrm{Ce}\left(\mathrm{Co}_{0.30}, \mathrm{Ni}_{0.40}, \mathrm{Cu}_{0.15}, \mathrm{~V}_{0.10}, \mathrm{Fe}_{0.05}\right) \mathrm{O}_{3}$ \\
5 & $\mathrm{Ce}\left(\mathrm{Co}_{0.35}, \mathrm{Ni}_{0.40}, \mathrm{Cu}_{0.10}, \mathrm{~V}_{0.10}, \mathrm{Fe}_{0.05}\right) \mathrm{O}_{3}$ \\
6 & $\mathrm{Ce}\left(\mathrm{Co}_{0.40}, \mathrm{Ni}_{0.40}, \mathrm{Cu}_{0.05}, \mathrm{~V}_{0.10}, \mathrm{Fe}_{0.05}\right) \mathrm{O}_{3}$ \\
7 & $\mathrm{Ce}\left(\mathrm{Co}_{0.40}, \mathrm{Ni}_{0.40}, \mathrm{Cu}_{0.10}, \mathrm{~V}_{0.05}, \mathrm{Fe}_{0.05}\right) \mathrm{O}_{3}$ \\
8 & $\mathrm{Ce}\left(\mathrm{Co}_{0.35}, \mathrm{Ni}_{0.35}, \mathrm{Cu}_{0.15}, \mathrm{~V}_{0.10}, \mathrm{Fe}_{0.05}\right) \mathrm{O}_{3}$ \\
9 & $\mathrm{Ce}\left(\mathrm{Co}_{0.35}, \mathrm{Ni}_{0.35}, \mathrm{Cu}_{0.20}, \mathrm{~V}_{0.05}, \mathrm{Fe}_{0.05}\right) \mathrm{O}_{3}$ \\
10 & $\mathrm{Ce}\left(\mathrm{Co}_{0.35}, \mathrm{Ni}_{0.45}, \mathrm{Cu}_{0.15}, \mathrm{~V}_{0.05}\right)_{x} \mathrm{O}_{3}$ \\
11 & $\mathrm{Ce}\left(\mathrm{Co}_{0.35}, \mathrm{Ni}_{0.45}, \mathrm{Cu}_{0.10}, \mathrm{~V}_{0.10}\right)_{x} \mathrm{O}_{3}$ \\
12 & $\mathrm{Ce}\left(\mathrm{Co}_{0.35}, \mathrm{Ni}_{0.45}, \mathrm{Cu}_{0.05}, \mathrm{~V}_{0.15}\right)_{x} \mathrm{O}_{3}$ \\
13 & $\mathrm{Ce}\left(\mathrm{Co}_{0.40}, \mathrm{Ni}_{0.40}, \mathrm{Cu}_{0.15}, \mathrm{~V}_{0.05}\right)_{x} \mathrm{O}_{3}$ \\
14 & $\mathrm{Ce}\left(\mathrm{Co}_{0.40}, \mathrm{Ni}_{0.40}, \mathrm{Cu}_{0.10}, \mathrm{~V}_{0.10}\right)_{x} \mathrm{O}_{3}$ \\
16 & $\mathrm{Ce}\left(\mathrm{Co}_{0.40}, \mathrm{Ni}_{0.40}, \mathrm{Cu}_{0.05}, \mathrm{~V}_{0.15}\right)_{x} \mathrm{O}_{3}$ \\
17 & $\mathrm{Ce}\left(\mathrm{Co}_{0.35}, \mathrm{Ni}_{0.45}, \mathrm{Cu}_{0.20}\right)_{x} \mathrm{O}_{3}$ \\
18 & $\mathrm{Ce}\left(\mathrm{Co}_{0.40}, \mathrm{Ni}_{0.45}, \mathrm{Cu}_{0.15}\right)_{x} \mathrm{O}_{3}$ \\
19 & $\mathrm{Ce}\left(\mathrm{Co}_{0.40}, \mathrm{Ni}_{0.40}, \mathrm{Ni}_{0.40}, \mathrm{Cu}_{0.25}\right)_{x} \mathrm{O}_{3}$ \\
\end{tabular}

\section{Results and discussion}

In this study, some of the remarkable features from the investigation of new 19 ceria based anode samples are presented.

It is well known that the ratio of glycine/nitrate, $\mathrm{pH}$, heating rate, and reaction temperature all affect the morphology and properties of synthesized powders from the GNP process [12-14]. In this article, the effect of additives such as $\mathrm{Cu}, \mathrm{V}$ and $\mathrm{Fe}$ to ceria doped $\mathrm{Co}-\mathrm{Ni}$ anode material on the powder morphology and other physical features was investigated. The reactor tank and the combustion/reaction conditions also strongly influence the physical and chemical features of the synthesized powders. It is thought that the transformation reactions occur in a much shorter time frame compared to the normal combustion method due to a very high pressure and possibly high temperatures and lack of sufficient oxygen inside the closed container reactor. For this reason, it was determined that synthesized powders had smaller particle size (see Fig. 1), high specific surface area (see Fig. 2) and some transition metals were in metallic and intermetallic forms (see Fig. 3).

Particle size analyses were conducted for both the reference and the new samples in pure water $(\mathrm{pH} 7)$ without pH and zeta potential controls. The sample No. 19 was produced in a container open to the atmosphere. For true particle size analysis, the dispersion of powders in a liquid medium, $\mathrm{pH}$ and zeta potential controls are very important. All elements added to ceria $(\mathrm{Cu}, \mathrm{Co}, \mathrm{Ni}, \mathrm{V}$ and $\mathrm{Fe}$ ) have been found to contribute to an increase in grain size and a decrease in specific surface area as shown in Fig. 2. Since there are numerous components in the 


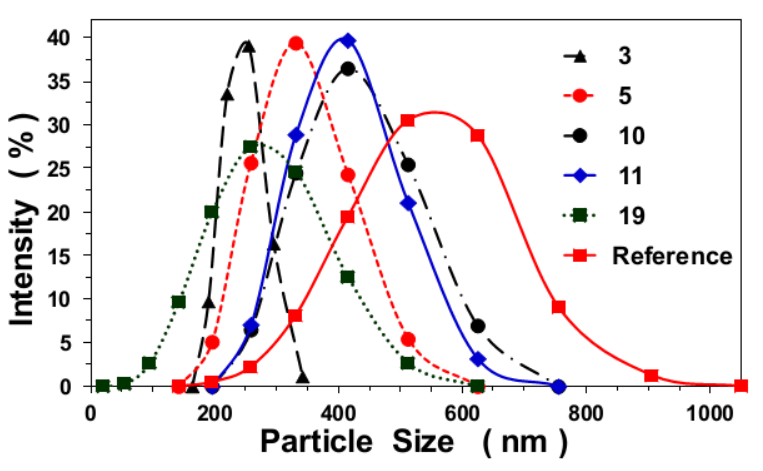

Fig. 1. Particle size distribution of ceria based nanopowders.

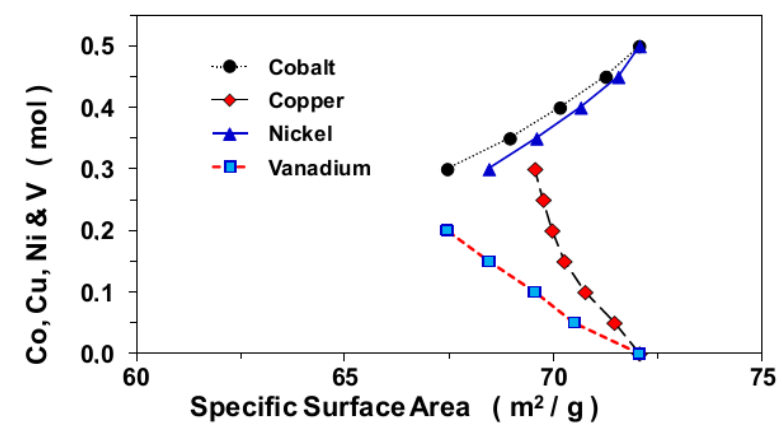

Fig. 2. Specific surface area of ceria based nanopowders as a function of different additives.

system, it is difficult to differentiate the effect of each one individually. However, the effect of each component on specific surface area was analyzed in Fig. 2 to improve the understanding of results due to individual additives.

As seen in Fig. 3, it was observed after the combustion reaction that the ceria and a pure metal and intermetallics were formed along with metal oxides since the reactions took place without adequate oxygen in closed

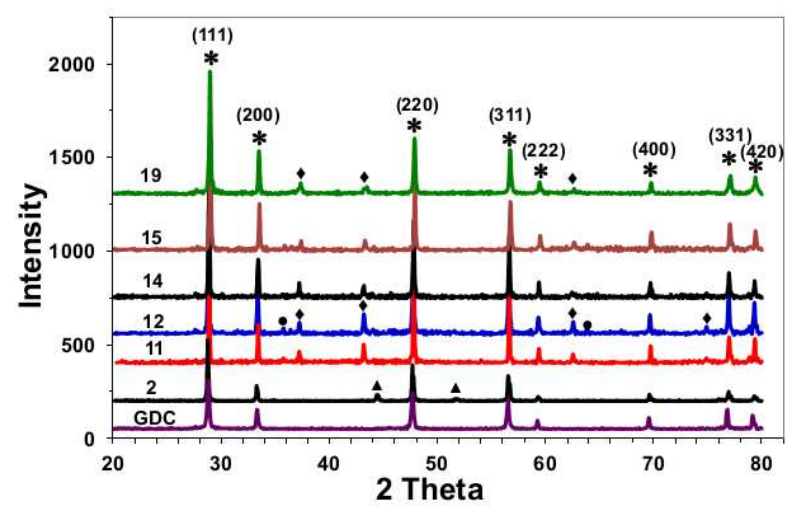

Fig. 3. XRD analysis of ceria based nanopowders (* doped ceria or GDC, $\boldsymbol{\Delta} \mathrm{Co}, \nabla \mathrm{Ni}-\mathrm{Co}-\mathrm{Cu}$ oxide and $\bullet$ intermetallics). containers (Fig. 3). XRD analysis indicated a difference in chemical compositions of Gd doped ceria and other samples (samples 2, 11, 12, 14, 15, 19, and GDC in Fig. 3). It was observed that $\mathrm{Co}, \mathrm{Ni}$ and $\mathrm{Cu}$ added to the ceria was dissolved in the crystal structure, however, the addition of $\mathrm{V}$ and $\mathrm{Fe}$ led to the formation of various metals and intermetallics $\left(\mathrm{Co}, \mathrm{FeNi}_{3}, \mathrm{Cu}_{2.7} \mathrm{Fe}_{6.3} \mathrm{Si}\right.$ ) and other oxides (cobaltite, magnetite). From the DSC analysis in Fig. 4, it was seen that oxide formation is not completed during the production stage and various exothermic reactions and oxidation that take place during the heat treatment of the powders depending on the type and amount of metallic and intermetallic forms.

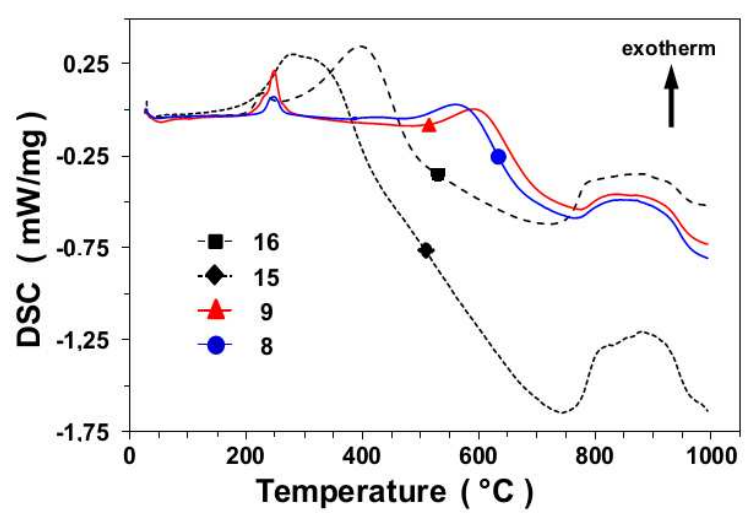

Fig. 4. DSC analysis of ceria based nanopowders.

As discussed earlier, the addition of $\mathrm{Co}, \mathrm{Ni}, \mathrm{Cu}, \mathrm{V}$, and Fe to the ceria based anode materials has a considerable effect on the morphology of the powders produced (see Fig. 5). While the effect on the morphology is varied, in general a formation of coarse-grained powder (reduction in specific surface area) was observed. Grains formed with the addition of $\mathrm{Cu}$ were found to have a spheroid structure and Fe was also found to be a contributor to this as well (see Fig. 5b). In the absence of $\mathrm{Cu}, \mathrm{V}$ and Fe a more rod-like but less dense (containing a large amount of pores) tuff-like morphology was observed. The addition of vanadium contributed to the closing of pores and a slight change in morphology towards a spherical shape (see Fig. 5a). Although they do not have a spherical agglomerate structure, the powder with the smallest particle size (largest specific surface area) was obtained from compositions with less $\mathrm{Cu}$ and $\mathrm{V}$ (see Fig. 5d).

The results of the analysis shown above clearly indicate that the type and amount of the additives in the ceria $(\mathrm{Co}, \mathrm{Ni}, \mathrm{Cu}, \mathrm{V}$, and $\mathrm{Fe}$ ) has a significant effect on the morphology and other characteristics of the powders produced. The type and amount of additives used along with the reactor (reaction vessel) and the reaction medium were all found to have significant effects on the size and composition (oxide, metal or intermetallic formation) of the powders formed.

The fact that the combustion vessel was closed, containing insufficient oxygen in the vessel, means that the 

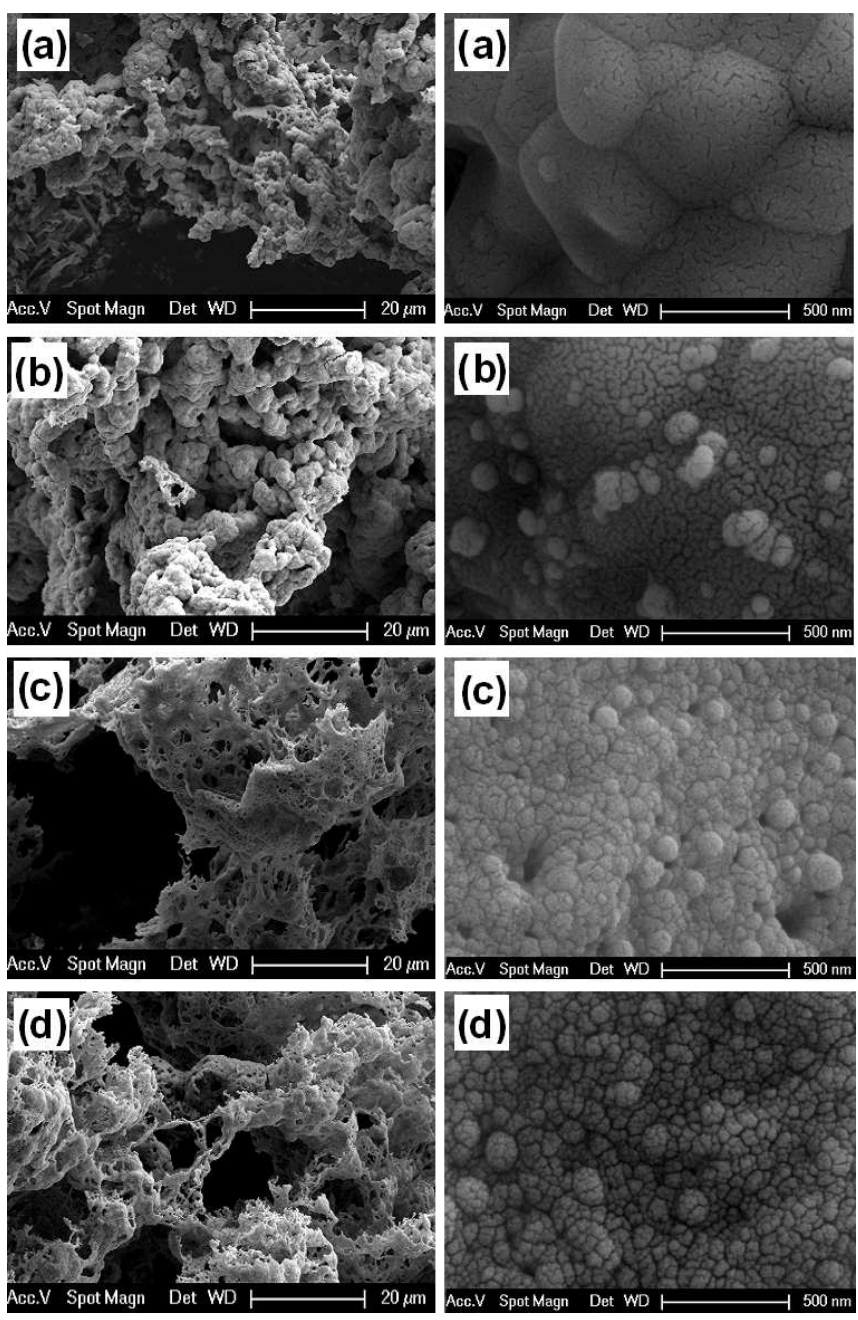

Fig. 5. Morphology of ceria based nanopowders synthesized by GNP. Samples: 4 (a), 8 (b), 11 (c) and $19(\mathrm{~d})$.

conversion reaction cannot be completed as in normal combustion reactions. As a result, the formation of pure metals and intermetallics is inevitable. It is thought that removing air and replacing it with pure oxygen to a certain extent (equivalent to level of atmospheric pressure) will be sufficient to attain high efficiency in the formation of oxides. However, the reason for this must be investigated to see whether that will increase the performance of the anode material. The effects of these results on the anode material and in turn on the SOFC system performance will be examined in the coming studies.

\section{Conclusions}

Reactor design and the conditions of the combustion reaction (pressure, temperature, oxygen ratio, etc.) have important effect on the physical and chemical properties of the synthesized anode nanopowders. The use of a close reactor system without oxygen feeder results in an absence of oxygen in the reaction and hence obtained powders become a mixture of metallic and intermetallic structures with powders representing their morphological properties such as small particle size distribution and high specific surface area. The addition of $\mathrm{Co}, \mathrm{Ni}, \mathrm{Cu}$, $\mathrm{V}$, and Fe into the ceria based anode material is found to have a considerable effect on the morphology of the powders. The samples with higher $\mathrm{Cu}$ ratios are found to form a structure with spherical morphology and the addition of Fe increases the formation of this spherical structure as a result of SEM analysis. In the absence of $\mathrm{Cu}, \mathrm{V}$ and Fe the powder morphology changed into a low density and soft agglomerated tuff-like structure (containing high amount of pores). The addition of vanadium resulted in close pore structure and shows a slight effect on morphology towards spherical shape. The smallest particle size (largest specific surface area) is obtained from compositions with less $\mathrm{Cu}$ and $\mathrm{V}$ content (high $\mathrm{Co}$ and $\mathrm{Ni}$ ratio) despite having a non-spherical and non-uniform agglomerate structure.

\section{Acknowledgments}

This work was supported by Turkish Ministry of Science, Industry and Technology and Kale Group under the contract San-Tez 00892.STZ.2011-1.

\section{References}

[1] P.A. Lessing, J. Mater. Sci. 42, 3465 (2007).

[2] K.S. Weil, C.A. Coyle, J.S. Hardy, J.Y. Kim, G.-G. Xia, Fuel Cells Bulletin 5, 11 (2004).

[3] J.M. Ralph, A.C. Schoeler, M. Krumpelt, J. Mater. Sci. 36, 1161 (2001)

[4] A.J. Mc Evoy, Fuel Cell Technology Status and Prospects, Laboratoire de Photonique et des Interfaces. Ecole Polytechnique Féderale de Lausanne, June 1998.

[5] E.P. Murray, T. Tsai, S.A. Barnett, Nature 400, 649 (1999)

[6] S. Park, J.M. Vohs, R.J. Gorte, Nature 404, 265 (2000)

[7] S. Mclntosh, R.J. Gorte, Chem. Rev. 104, 4845 (2004)

[8] T. He, Q. He, N. Wang, J. Alloys Comp. 396, 309 (2005).

[9] C.-C. Hwang, T-Y. Wu, J. Wan, J.-S. Tsai, Mater. Sci. Eng. B 111, 49 (2004).

[10] W. Wang, R. Ran, Z. Shao, Int. J. Hydrogen Energy 36, 755 (2011)

[11] C.-C. Hwang, T.-Y. Wu, J. Wan, J.-S. Tsai, Mater. Sci. Eng. B 111, 49 (2004).

[12] L.A. Chick, L.R. Pederson, G.D. Maupin, J.L. Bates, Mater. Lett. 10, 6 (1990)

[13] S.R. Nair, R.D. Purohit, A.K. Tyagi, P.K. Sinha, B.P. Sharma, Mater. Res. Bull. 43, 1573 (2008)

[14] R.K. Lenka, T. Mahata, P.K. Sinha, A.K. Tyagi, J. Alloys Comp. 466, 326 (2008) 